\title{
GROUP STEREOTYPES AND SYMBOLS OF OVERCOMING DIFFICULT SOCIAL SITUATIONS IN THE IMAGE OF SMALL GROUPS
}

\author{
Olha Pletka \\ Institute for Social and Political Psychology National Academy of Educational \\ Science of Ukraine, Kyiv, Ukraine
}

\begin{abstract}
.
Introduction. Sometimes a person meets with complex social situations. How a person lives these situations down? What is the experience that supports and drives a person to recovery? How does the group help for a person in this? These questions now arise for each of us, because there is no person in the world who would have had the experience of living in complex social situations

Purpose. The purpose of the article is to describe the results of the study of group stereotypes and the symbolism of complex social situations in small groups of different directions.
\end{abstract}

Methodology. The sample of empirical research is 132 individuals - 16 groups of different directions: therapeutic (2), educational (7) and crisis (5) (real groups that were in situations of conflict and crisis) and self-help groups (2). Selfhelp groups are a group of families of demobilized soldiers (heterogeneous) and a group of veterans.

The empirical study was conducted in 2 stages. In the first stage, the questionnaire "I am in the group" was prepared and tested. It consists of 21 questions and demographic data of the respondents (age, gender). In the second stage of the empirical study, the seminar "Difficult Social Situations: Experiences of Living and Overcoming" was conducted in the study groups, followed by a survey of respondents. The duration of the seminar is 3-4 hours, depending on the needs of the group

Results. The article presents the results of an empirical study of group stereotypes and symbols in the image of small groups in complex social situations. The research identified stereotypical perceptions of the group and overcoming difficult social situations, outlined by the author as external and intragroup stereotypes. External group stereotypes include the destructive, relatively destructive, conditionally constructive and constructive groups of stereotypes described by the respondents. The groups of stereotypes pertaining to external groups are described in detail: relatively destructive (Uniqueness, Closeness and Complexity) and conditionally constructive (Causality and Willingness). Intragroup stereotypes are indicated too. Also, the article highlights a number of group symbols and group processes highlighted by the respondents, describes the analysis of the results of the "Symbolization of experience" methodology. Typization of symbolization of complex social situations and ways of overcoming 
them is presented. The symbols of this process are determined by the respondents by those symbols that demonstrate the dynamics (or transformation) of the character itself, the dynamics of the plot development, and the abstract ones, which have internal, not obvious, outside logic. Examples of these characters are described.

Conclusion. The analysis of the results of the study showed that group stereotypes play a key role in predicting strategies for overcoming difficult social situations, and symbolizing this process helps to find support and help, both within and outside the group symbols

Keywords: symbols of a group, group stereotypes, a small group, group

The author declares that she has no competing interests

\section{References}

Bazikov RV (1999) Social stereotypes: conceptual aspect. (Cand. Dis. philosopher. R-na-D, 1999, 122 .

Samkova OM (2013) Social stereotypes and stereotyping: An analysis of contemporary theoretical approaches. Scientific Bulletin of Kherson State University. Psychological Sciences Series. 1, 68 - 71

Semashko T. F. (2015). Changing emphasis on understanding stereotype as a phenomenon of social practice. Scientific Bulletin of the UNESCO KNLU Series Philology Series. Pedagogy. Psychology. 30, 138 - 144

Shikhirev P.N. (1971). Stereotype studies in American social science. Philosophy Questions 5, 168-175.

Shihirev PN (1999) Modern social psychology. Moscow IP R AN; PCB +; Academic Project, 447 p 


\title{
Групові стереотипи та символи долання складних соціальних ситуацій в образі малих груп
}

\author{
Ольга Плетка \\ Інститут соціальної та політичної психології НАПН України, Київ, \\ Україна
}

Постановка проблеми. Людина опиняється в складних соціальних ситуаціях. Як вона проживає цей досвід, що іiі підтримує та спонукає до відновлення? Яким чином допомагає в цьому група, родина, частиною яких вона $€$ ? Ці питання постають наразі в кожного з нас, бо немає в світі людини, яку б минув досвід проживання складних соціальних ситуацій. Для когось це втрата коханої людини або батьків, для когось це звільнення з роботи ми по-різному розділяємо ці ситуації на складні та прості, але стратегії їх долання можуть бути схожими. Учасники малих груп можуть перебувати в індивідуальній складній ситуації, сама група може бути в цих умовах і які групові феномени сприяють пошуку оптимальних шляхів вирішення ситуації та відновлення після iї завершення. Практиками психологами наголошується ідея, що процес проживання складних соціальних ситуацій може відрізнятися у представників різних груп (за напрямом взаємодії, за якісною характеристикою складу групи, за груповим досвідом та терміном взаємодії). Однак наукові розвідки щодо свідомих та несвідомих феноменів під час групової взаємодії майже не проводяться із-за складності досліджень та обмеженості доступу до малих груп, які б могли проживати й характеризувати такі феномени в цілому. Натомість парціальне дослідження певних груп дозволяє зробити припущення та виявити тенденції щодо символізації отриманого групового та індивідуального у групі досвіду проживання складних соціальних ситуацій, а також виявити основні стратегії долання цих ситуацій та стереотипність уявлень щодо їх природи. Також сьогодення має нагальну потребу у розумінні цих процесів, у виявленні механізмів, що сприяють посттравматичному зростанню та розробленні певних засобів, які б спонукали суспільство до трансформації в умовах соціально складних ситуацій. Наразі відбувається формування нових стандартів життя, де індивідуальне стає суспільним, а суспільне має 
відображення у індивідуальному стилі життя. Віддзеркалюючи індивідуальне в груповому, а групове в індивідуальному, суспільство потребує певної символізації цих трансформацій та зрушення групових стереотипів щодо уявлень та розуміння ситуації в цілому та себе в ній зокрема. Зауважимо, що дослідження цих групових феноменів неможливо без пізнання тих символічних та стереотипних уявлень, в яких ці групи функціонують. У статті висвітлюються результати емпіричного дослідження означених групових феноменів.

Метою статті $є$ опис отриманих результатів дослідження групових стереотипів та символіки складних соціальних ситуацій в малих групах різного спрямування.

Виклад основного матеріалу. Дослідження групових стереотипів займалось багато вчених (Самкова О., 2013), вони описувати ті чи інші феномени. Так, П. Шихирев, осмислюючи соціальні стереотипи, наголошував, що стереотипізація «поєднує в собі ірраціональні і раціональні риси» (1971, с. 168-175). Він також виділив основні його функції, а саме: спрощення, категоризація й систематизація, які пов'язані $з$ процесами економії зусиль i захистом групових цінностей. Також П. Шихирев виділяв жорстку фіксованість стереотипу, його афективна насиченість i поляризацію оцінки, пояснюючи це тим, що він $\epsilon$ персоніфікованим відтворенням стосунків між соціальними об'єктами i оцінками цих стосунків, не виділяючи при цьому соціальний статус суб'єктів взаємодії (1999, с. 273).

Однак Т. Семашко (2015) виділяє декілька функцій стереотипів і зауважує, що

стереотип є структурною частиною свідомості (ми можемо його виявити у формі норм, традицій, вірувань, настанов), що це схематизована, спрощена характеристика соціальних об'єктів чи явищ достатньо стійкий образ або уявлення щодо них. Вона наголошує, що основою стереотипу є оцінка та уявлення про соціальні об'єкти і він може розглядатися як спосіб групової ідентифікації. При цьому стереотипізація, категоризуючи навколишнє, дозволяє спростити сприймання соціального оточення індивіда чи групи. 
Цікавими для нашого дослідження стали наробки Р. Базікова (1999), який розглядав стереотипи індивідуального та групового (колективного) рівня. Він наголошував, що стереотипи індивідуального рівня це стійкі уявлення про соціальні об’єкти незалежно від характеру взаємодії з ними. Натомість стереотипи групового рівня, на його думку, це жорсткий зв'язок між «системою соціальної взаємодії і прийнятої в групі системою поглядів на навколишній світ», де важливим є порядок реалізації певних дій, притаманний цій соціальній групі. Він також зазначає, що стереотипи обох рівнів мають у своїй структурі когнітивний, афективний і соціальний компоненти, які, поєднуючись, й складають цю структуру. Р. Базіков також розділяе функції індивідуальних та групових стереотипів. На його думку індивідуальні стереотипи несуть в собі інформаційну, аксіологічну i цілепокладаючу функції, а групові ще й ідентифікаційну, нормативнорегулятивну і інтеграційну функції.

Вибірка емпіричного дослідження складає 132 особи - 16 груп різного спрямування: терапевтичного (2), навчального (7) та кризового (5) спрямування (реальні групи, які перебували у ситуаціях конфлікту та кризи) й групи самодопомоги (2). Опишемо ці групи. Групи самодопомоги - це група родин демобілізованих військовослужбовців (гетерогенна) та група ветеранів ATO/OCC (гомогенна). Терапевтичні групи є гомогенними та складаються 3 учасниць різних вікових та статусних категорій, які виявили бажання відвідувати ці групи. Групи навчального спрямування (гетерогенні) складаються з психологів дошкільної та шкільної освіти, відвідувачів курсів підвищення кваліфікації. Групи кризового спрямування гетерогенні й складаються з осіб, що працюють разом та перебувають на час дослідження у складній соціальній ситуації.

Емпіричне дослідження проводилось у 3 етапи. На першому етапі складалася й проходила апробація анкета «Я у групі» Вона складається 321 питання та демографічних даних респондентів (вік, стать). Питання відкритого типу та містять інформацію $з$ уявлень опитуваних про складні соціальні ситуації, стереотипність взаємодії, символізацію власного й групового досвіду та символів групи, членами якої вони є. Також в анкеті присутні питання про звичні стратегії подолання наслідків складних 
соціальних ситуацій. На другому етапі емпіричного дослідження у досліджуваних групах проводився семінар «Складні соціальні ситуації: досвід проживання й долання» 3 подальшим опитуванням респондентів. Семінар мав наступну структуру: знайомство з ведучим, очікування від семінару; дискусія щодо складних соціальних ситуацій та їх подолання самостійно, в групі чи в родині; рольова гра «Підтримай мене», метою якої був пошук підтримки за умови переживання складної соціальної ситуації та демонстрація можливих стратегій подолання; обговорення отриманого досвіду; заповнення анкети «Я у групі» та виконання авторської методики «Символізація досвіду», де респонденти малювали три малюнки й описували зображені символи складної соціальної ситуації, стратегії іï долання та інтеграції отриманого досвіду у власне життя. Тривалість семінару 3-4 години в залежності від потреби групи. Наразі триває третій етап дослідження - це аналіз отриманих результатів.

Ми розділяємо групові процеси на зовнішньо-групові та внутрішньогрупові, розуміючи, що вони можуть бути різними і вирізняться як цілями так і характером взаємодії. Розглянемо стереотипні уявлення респондентів щодо долання складних соціальних ситуацій, спираючись на вектор взаємодії (назовні чи всередині) групи. Так, виявлені стереотипи щодо зовнішнього вектору взаємодії можна поділити на групи, що об’єднують в собі низку уявлень, якими керуються учасники груп під час проживання складних соціальних ситуацій. Ми їх поділили на деструктивні, відносно деструктивні, умовно-конструктивні та конструктивні або дієві. До групи деструктивних стереотипів можна віднести ситуації, коли людина не справляється та руйнує власне життя під час проживання складної для неї соціальної ситуації або руйнує свою взаємодію в групі та з групою. При груповому процесі такі дії призводять до виходу з групи, переривання контактів з їі членами та таке інше. Зважаючи на той факт, що досліджувані групи не мали в своій основі ситуацій, коли хтось залишав групу з причини нездатності іï вирішення іншим шляхом чим піти, то ми й не спостерігали під час роботи з групами означених дій. Цікаво, що респонденти навіть не розглядали такої можливості - покинути групу. I це при тому, що вихід 3 групи може бути достатньо позитивним для особи, яка вийшла $з$ неї і таке 
рішення може змінити статус ситуації зі складної на таку, що має в своїй основі рішення за рахунок зміни складу групи або повного іiі розпаду. До конструктивних або дієвих ми відносимо ті стереотипи, які дозволяють вирішувати ситуацію, залучаючи всіх членів групи та сторонніх фахівців. Такі дії залишають за собою шлейф успішності групи і ситуація теж трансформується зі складної на таку, яку вони здатні подолати, а значить вона не була настільки складною. Відносно-деструктивні та умовноконструктивні групи стереотипів - це ті стереотипи, які не дозволяють групі справитися зі складною соціальною ситуацією, але різними способами: відносно-деструктивні за рахунок «зависання» в ситуації, а умовноконструктивні за рахунок імітації дій або дій, які не сприяють зміні ситуації. Опишемо більш детальніше ці загальні стереотипні уявлення учасників досліджуваних груп.

Так, загальними стали стереотипи, які виділяються ізольованістю та бажанням виокремити свою ситуацію від ситуацій, які проживали інші люди чи групи людей: цฺе моє, ніхто інший не зрозуміє мене й мою ситуащію. Ми назвали цю групу стереотипів «Унікальність». Ця група стереотипів позначається висловами: «ми не знали що робити, бо ніхто не робив цього раніше», «нашу біду люди не зрозуміють», «краще промовчати». «не треба просити про допомогу», «нам ніхто не допоможе», «який психолог пойме, що зі мною», «просити про допомогу соромно». Як пояснювали в бесіді учасники груп, для них важливим $є$ розуміння, що треба зі своїм горем справлятися самотужки, бо ніхто не зможе його дати раду. Такі уявленні характерні для стадії ізольованості під час кризових переживань. Але, як ми спостерігаємо, людина може залишитися на цій стадії довгі роки й психологічно продовжувати перебувати в минулій складній ситуації, що в свою чергу може призвести до ситуації, коли теперішні події проживаються як неважливі та несуттєві. Таке акцентування на минулому досвіді потребує уваги з боку фахівців, але людина, перебуваючи у такому стані не може критично аналізувати власні стани. Також звертає на себе увагу й професія учасників груп (воєнні, психологи). Навчені долати перешкоди самотужки, привчені до розуміння себе як сильної особи, вважають, що отримання зовнішньої допомоги може бути ознакою слабкості та фактично показу себе 
безпомічними у кризовій події, що не припустимо з точки зору професійної компетенції, а також можливість отримання допомоги спростовує ореол унікальності самої ситуації та розміщує іiі у низці інших, притаманних та прожитих багатьма людям.

Наступною загальною для груп стала низка стереотипів, які ми назвали «Закритість». Цей стереотип позначається наступними виразами: «все ОК», «нічого страшного, справляємося», «якось буде», «так нічого не сталося». Для виявленого стереотипу характерно знецінення власних переживань, спроба за будь яких обставин зберегти ілюзію благополуччя, або перекреслити, витіснити подію, не проживши іiі. Таке когнітивне узагальнення також демонструє психологічні захисні механізми, коли переживання складної соціальної ситуації спричинює нестерпний емоційний біль й не має можливості з ним справлятися. Вміння стримувати себе, приховувати первинні емоційні стани також $є$ результатом професійних компетенцій, які в умовах, наприклад демобілізації (у групах ветеранів АТО/ООС) вже можуть бути відхилені, але по інерції продовжують діяти.

Група стереотипів, яку ми назвали «Складність», позначається словами та виразами «і що Ви можете тут зробити», «а що є хтось, хто допоможе», «другим потрібніше», «і що буде», «на що Вам мої проблеми». Для цього комплексу стереотипних уявлень характерно: не віра у дієвість допомоги, у компетентність допомагаючих 3 одного боку й навмисне зменшення потреби в сторонній допомозі з іншого. Це як ставити у сумнів результативність допомоги, ніби промовляючи: якщо у Вас нічого не вийде, то що 3 цього буде, краще б не починали. Таке ставлення до можливої допомоги ніби підкреслює складність переживання 3 яким не можливо справитися навіть професіоналам. Тобто людина каже собі: це нестерпно, 3 таким люди не можливо справитися й ніхто не зможе допомогти. Таке ставлення до своїх станів показує, що людина знаходиться у стадії відмови в процесі переживання кризової події, коли такого зі мною не могло статися або таке пережити неможливо.

Групи стереотипів «Унікальність», «Закритість» та «Складність» ми позначили як відносно деструктивні, бо вони не уособлюють групу або 
людину залишатися сам на сам з ситуацією, «зависати» в ній і не шукати рішень.

Іншим, більш конструктивним на перший погляд, є масив уявлень, який можна назвати «Каузальність» (причиність). Він виявляється наступними висловами: «оце в мене так і чому», «я не знаю, що 3 цим робити», «в мене так завжди після події», «немає виходу», «не розумію нащо це мені» та інші. Характерним поясненням такого стереотипу є готовність до розуміння механізмів та чинників вирішення проблеми, що виникла в наслідок складної соціальної ситуації. Зовнішньо це виглядає як готовність до дії, але при цьому людина має готовність, а не наснагу почати діяти. В неї немає мотиву: розкажіть і я зроблю. Такі люди потребують постійної уваги з боку фахівців, але очікувати результативність кризового втручання марна справа, людина занурюється у пояснення чому так сталося і не має наснаги змінити ситуацію.

Також цікавою для нашого дослідження виявилася група стереотипів, яку ми назвали «Готовність». Вона також може бути віднесеним до умовно конструктивних, бо описується словами: «я все зроблю, що Ви скажете», «треба прислухатися й діяти», «як скажете», «я спробую». Зауважимо, що при такому активному та діяльнісному підході справа ніби може зрушитися, але готовність ще не означає відповідальну стратегію подолання власних станів. Так можливим результатом взаємодії може стати вислів: Я все робив як Ви сказали й нічого не вийшло. Даний стереотип демонструє інфантильне бажання бути керованим й не нести відповідальність або не мати бажання долати кризові стани. Зазвичай особи, які керуються цим стереотипом, у групі промовляють про багато перешкод на шляху подолання, виявляючи неможливість цілеспрямовано діяти або, маючи неусвідомлену вигоду від власного стану, імітують свою активність. Стереотипи «Каузальність» та «Готовність» були віднесені до умовно конструктивних, бо спонукають думати про подію, шукати причини іiі виникнення, але не сприяють іï вирішенню.

Нами помічено, що кожна група стереотипів проявляється в групі в тій чи іншій мірі. Розпізнавання їх, проговорення у групі, акцентування уваги учасників до їх проявлення сприяє усвідомленому включенню 
кожного у процес подолання кризових станів. Зважаючи на те, що зворотній зв'язок також спонукає вчитися іншим стратегіям, а спостерігання за іншими учасниками дозволяє припустити, що переживання можуть бути схожими, що фахівців можуть надати допомогу та таке інше, учасники набувають нових для них вмінь взаємопідтримки та розділення власного досвіду подолання наслідків складних соціальних ситуацій.

Отже, описані вище групи стереотипів показують, що груповий процес проявляє ті стереотипи, що є загальними для учасників і які не сприяють результативності роботи. Також важливим є зауваження, що без активної участі кожного не можливо подолання наслідків складних соціальних ситуацій. Виділені стереотипи показують етапи виходу 3 кризових станів та наочно формують в учасників уявлення щодо власних стратегій успіху/неуспіху виходу з травмуючих переживань. Описані вище групи стереотипів стосуються зовнішньої поведінки групи у складних соціальних ситуаціях, яку їі учасники демонструють назовні іншим групам та окремим особам.

Респондентами означена низка стереотипів, які на їх думку існують у групі, і які ми можемо співвіднести до внутрішньо-групових. Деякі стереотипи позначені способом дії, а деякі мають ствердження щодо характеру цієї дії. Характерними для груп респондентів виявилися стереотипи: «нав'язливий - смішується $i$ заважає; байдужий відсторонюється», «одні працюють, другі - ніби "працฺюють", не заважать, а треті - "користуються ентузіазмом"», «хай все вирішує лідер, без мене впораються», «хтось( лідер, має витягувати групу)», «пізнавальна активність цее круто, любов до дітей нас об'єднує, працювати в освіті изе подвиг», «приймати думку іншого, не завжди обтрунтовувати», «комплекси nсихологів». «Стандартом» дії у групі або іiі стереотипами щодо взаємодії респонденти виділили наступні характеристики: вміння слухати, чути, рамки, розслаблення, креативність, розуміння, толерантність, егоїзм, наслідування, згуртованість, повага та розподіл ролей. Натомість серед визначених міфів стосовно своєї групи респонденти зазначили такі: ми всі 3 90-х, ми просто схожі, психолог - це життя!, "Я знаю краще, у мене в житті таке було", психолог може все, біблійські легенди про створення 
cвimy, в групі працฺювати иџікаво. Контент аналіз показав, що респонденти у групах часто дають однакові відповіді на питання, що може бути пов'язано 3 синергічним зв'язком учасників груп. Вище ми зазначили, що учасники груп, що опинилися в кризових умовах, відчувають спорідненість один 3 одним, об’єднані спільним «горем» та долають ситуацію групою, не розділяючись задля вирішення питання самотужки.

Цікавими виявилися й особливості символізації групи, ситуацій та стратегій виходу 3 них. Зупинимось детальніше на символах групи та групових символів. Символ групи - це метафоричне позначення саме групи, членом якої є респондент, а групові символи - це символи, які позначають процеси, що відбуваються у групі чи дії, які характерні під час взаємодії в ній. Серед символів групи слід особливо виділити низку природних об’єктів, якими позначають групу респонденти. Однак лідером серед символів став образ «зірки», що може вказувати на здатність учасників груп до відновлення. Виокремлені символи групи та групові символи складної ситуації показано в таблиці.

Таблиця

Символи у груповому процесі

\begin{tabular}{|c|c|}
\hline $\begin{array}{l}\text { Групов } \\
\text { i }\end{array}$ & $\begin{array}{r}\text { Са } \\
\text { ме групи }\end{array}$ \\
\hline $\begin{array}{c}\text { простяг } \\
\text { нуті долоні }\end{array}$ & $\begin{array}{l}\text { три } \\
\text { кутник } \\
\text { (ієрархія) }\end{array}$ \\
\hline опора & $\begin{array}{l}\text { буд } \\
\text { иночок }\end{array}$ \\
\hline $\begin{array}{l}\text { сонечк } \\
\text { о, яке зігріває } \\
\text { промінцями }\end{array}$ & ечко \\
\hline любові $^{\text {коло }}$ & кол \\
\hline серце & це сер \\
\hline людей $^{\text {коло }}$ & яшник $^{\text {coн }}$ \\
\hline
\end{tabular}




\begin{tabular}{|c|c|}
\hline їжак & вул \\
\hline $\begin{array}{l}\text { нескінч } \\
\text { енність }\end{array}$ & $\begin{array}{l}\text { рія } \\
\text { фантазій }\end{array}$ \\
\hline дуб & сад \\
\hline злам & зip \\
\hline стіг & ти \\
\hline $\begin{array}{l}\text { кучка } \\
\text { попелу }\end{array}$ & $\ll 5 »$ \\
\hline книга & мішки \\
\hline
\end{tabular}

В таблиці показано низ ку символів, виділених респондентами, деякі з яких схожі як для групових процесів, так і для позначення саме групи. Натомість це символи усіх учасників груп і нами не виявлено однакових символів зазначених характеристик ні в одного респондента. Тобто у кожного респондента ці символи чітко відрізняються, але вони можуть повторюватися у характеристиках різних груп. Колонки у таблиці $\epsilon$ самостійними і не співвідносяться одна з одною за символами, нами лише виокремлені символи, які обрали респонденти.

Аналіз малюнків за авторською методикою «Символізація досвіду» показав, що символи, якими позначають респонденти складні соціальні ситуації та стратегії їх долання можна поділити на три групи: 1. Ті, що демонструють динаміку символу, 2. Ті, що показують динаміку розвитку сюжету та 3. Абстрактні або ті, що мають внутрішню логіку, яка не доступна на зовні. Розглянемо їх більш детально. Так, малюнки учасників першої групи, на яких символи мають спільні елементи та показують трансформації первинного символу, тобто демонструють динамічність символу, наприклад, 1 малюнок - дерево зі зламаними гілками, 2- обрізання пошкоджених гілок, 3- квітуче дерево. Так, нами виокремлена низка символів, що використовується найбільше: дерева (на початку зламані, пошкоджені, а наприкінці квітучі), свічки (на початку плавлені, а в кінці на 
підставочці, рівні), нитки ( на початку заплутані, а наприкінці - вже у клубку чи у виробі), дороги (заплутані - прямі), образи війни (бомба на початку та кафе Ветерано - наприкінці), вогнища (польові - факели), двері (замкнені та $з$ ключами), чарівні істоти (дракон та зображення дракону на щиті), блискавки (страшні на чорному небі та маленькі на світлому фоні (як весняні грози), дощ (злива спочатку і літній дощик наприкінці).

Інша група символів має динаміку розвитку сюжету. А саме: дощ парасолька -сонячна погода; гроза - сонечка 3-за хмар - веселка; двоє чоловічків 3 телефонами - перекреслений телефон - стіл 3 чашками духмяної кави; вибух - дерево біля хати - огорожа навколо хати та сонечко; зав'язана мотузка - ніж - факел з мотузки; гроза - сонечко - літній дощик й квітучі рослини; хаос ліній - різні фігури - квіточка з цих фігур; багаття відро, що його гасить - колодязь; прихована яма - стежка - квіти, що ростуть замість ями та інші.

Ми також виділили групу символів, що мають абстрактну природу, динаміку та логіку якої без пояснень автора не можливо зрозуміти. Наприклад, знак блискавки - знак оклику - символ серця; шахове поле дівчина на дорозі - прямокутник, що окреслює дорогу; чоловічки - книга будинок з надписами; діючий вулкан - метелик - пташка, що летить; квадрат з хвилястими лініями по діагоналі - стрілка у колі, спрямована вправо вверх - пів стріли, спрямованої прямо вверх 3 хвилястими вертикальними лініями; зірка у колі - сонечко з промінцями - сонечко у колі; нахилена рещітка - хмарка - об’єкт, що нагадує хмарку з прямими вставками; пухнастий куля - коло 3 зафарбованим боком - дерево 3 каштанами на ньому та ьіля нього; миш - сонечко - метелик; хвилі 3 завірюхою зверху - знак смайлика - посмішки - чоловічок 3 квіточкою; прямокутник - драбина та знак серця - серце, пробите стрілою; лінія, що складається у фігуру, яка нагадує символ радіації - стріла, спрямована вверх - сонечко зі стрілою; знак безкінечності - рогатка - рогатка з ласо.

Отже символи, якими респонденти позначають складні соціальні ситуації та інтеграцію цих ситуацій у канву власного життя мають певні характеристики і можуть бути розділеними на 3 групи: 1. символи, що демонструють динаміку розвитку самого символу; 2. символи, що показують 
сюжетну динаміку; 3. символи, що мають абстрактну природу й власну внутрішню логіку, яку складно «прочитати» та зрозуміти сторонньому спостерігачу. Вважаємо, що розшифровка символів за допомогою відомих інтерпретацій може збагатити розуміння процесу, але й водночас «піти за дослідником», нехтуючи задумкою та значенням, які вкладав респондент, виконуючи методику. Тому ми не надаємо можливі значення тих чи інших символів, а залишаємо це питання відкритим для роздумів та інтерпретацій тими, кому цікаво пізнання таких групових феноменів.

Висновки. Проведене емпіричне дослідження окреслило коло аналізу питань стереотипізації та символізації групового й індивідуального досвіду долання складних соціальних ситуацій. Виділені стереотипи зовнішнього та внутрішнього характеру взаємодії. Згруповані нами стереотипи реагування на складні соціальні ситуації умовно можна розділити на деструктивні, відносно деструктивні, умовно конструктивні та конструктивні щодо пошуку рішень виходу з них. Символізація досвіду дозволяє інтегрувати його в життя, відшукати надбання й втрати та вміти справлятися зі схожими ситуаціями.

Аналіз результатів дослідження показав, що групові стереотипи відіграють ключову роль у прогнозуванні стратегій долання складних соціальних ситуацій, а символізація цього процесу сприяє пошуку підтримки й допомоги як в середині групи, так і назовні. Образ малої групи в такому разі формується з низки групових та індивідуальних стереотипів учасників групи та символів, якими вони позначають свою групу. 